\title{
Sale of luxury goods on the Internet in light of CJEU's judgment of 6 December 2017 in Coty Germany case and the research in the field of marketings
}

\author{
Sprzedaż towarów luksusowych w Internecie \\ w świetle orzeczenia TSUE z 6 grudnia 2017 r. w sprawie Coty Germany \\ i badań z zakresu marketingu
}

\author{
Dr Bartosz Targański \\ Szkoła Główna Handlowa, Instytut Międzynarodowego Zarządzania i Marketingu, \\ Katedra Biznesu Międzynarodowego \\ e-mail: btarga@sgh.waw.pl
}

\begin{abstract}
The purpose of this article is to discuss the potential impact of preliminary ruling of the Court of Justice of the European Union (CJEU) in the Judgment of 6 December 2017, Coty Germany, C-230/16 (the "Coty Judgement" or the "Judgement") on distribution of luxury products on the Internet. The impact is discussed from the perspective of research on luxury products in the field of marketing. In view of divergent positions of competition authorities in the EU regarding online distribution in recent years, it was expected that the Coty Judgment would increase legal certainty in this important market area. The author concludes that this impact will be rather limited. In essence, the Judgement accepted that bans on the sale on Internet platforms are justified measure to preserve the luxury character of goods. However, CJEU did not provide clear criteria for declaring products to be luxurious, which may open the way for further interpretation disputes. Due to this fact, the author reviewed to what extent the reasoning of CJEU can be supported by the research on the marketing of luxury products on the Internet. The research in the field of marketing supports the legitimacy of the prohibition to use Internet platforms for selling luxury products. The article shows that the research in the field of marketing could contribute to the enforcement of competition law.
\end{abstract}

Keywords

luxury products, selective distribution, online sales, Internet platforms

Celem artykułu jest analiza potencjalnego wpływu orzeczenia prejudycjalnego Trybunału Sprawiedliwości Unii Europejskiej (TSUE) z dnia 6 grudnia 2017 r. w sprawie Coty Germany, C-230/16 („Orzeczenie Coty” lub „Orzeczenie”) na dystrybucję towarów luksusowych $\mathrm{w}$ Internecie. Analiza zostanie przeprowadzona z perspektywy badań na temat produktów luksusowych w literaturze marketingowej. Wobec rozbieżnych stanowisk organów konkurencji w UE w ostatnich latach odnośnie dystrybucji internetowej oczekiwano, że Orzeczenie Coty zwiększy pewność prawa w tym istotnym obszarze rynku. Autor konkluduje, że wpływ ten będzie raczej ograniczony. TSUE uznał bowiem, że zakaz sprzedaży na platformach internetowych jest uzasadniony ochroną luksusowego charakteru towarów. TSUE nie podał jednak jasnych kryteriów decydujących o uznaniu produktów za luksusowe, co może otwierać pole do dalszych sporów interpretacyjnych. W związku z tym autor przeanalizował, w jakim stopniu Orzeczenie Coty może być poparte wynikami badań naukowych dotyczących marketingu towarów luksusowych w Internecie. Badania z zakresu marketingu wspierają zasadność zakazu wykorzystywania platform internetowych do sprzedaży produktów luksusowych. Artykuł wskazuje, że badania z zakresu marketingu mogą być przydatne w stosowaniu prawa konkurencji. 
towary luksusowe, selektywna dystrybucja, sprzedaż w Internecie, platformy internetowe

JEL: K21, M16, F23

Str. $40-44$

\section{References}

Cicala, A., Haegeman, K., \& Cuff, R. (2017). From Metro to Coty: A story to be continued? The CJEU's judgment in Coty Coty Germany GmbH v Parfümerie Akzente GmbH. Italian Antitrust Review, 4(2), 99-111. http://dx.doi.org/ 10.12870/iar-12854

Corneo, G. \& Jeanne, O. (1997). Conspicuous consumption, snobbism and conformism. Journal of Public Economics, 66(1), 55-71. https://doi.org/10.1016/S0047-2727(97)00016-9

Dall'Olmo Riley, F., \& Lacroix, C. (2003). Luxury branding on the Internet: Lost opportunity or impossibility? Marketing Intelligence \& Planning, 21(2), 96-104, https://doi.org/10.1108/02634500310465407

European Commission statement of 8 December 2017. Available at http://ec.europe.eu/newsroom/index.cfm?service_id=221 Judgment of 23 April 2009, Copad, C-59/08.

Judgment of 13 October 2011, Pierre Fabre Dermo-Cosmétique, C-439/09.

Judgment of 6 December 2017, Coty Germany, C-230/16.

Kapferer, J. N. (1997). Managing luxury brands. Journal of Brand Management, 4(4), 251-260. https://doi.org/10.1057/ bm.1997.4

Liu, X., Burns, A. C., \& Hou, Y. (2013). Comparing online and in-store shopping behavior towards luxury goods. International Journal of Retail \& Distribution Management, 41(11/12), 885-900. https://doi.org/10.1108/IJRDM-012013-0018

Nueno, J.L. \& Quelch, J. (1998). The mass marketing of luxury. Business Horizons, 41(6), 61-69. https://doi.org/10.1016/S0007-6813(98)90023-4

Nyeck, S. \& Roux, E. (1997). WWW as a communication tool for luxury brands: Compared perception of consumers and managers. In B. van Raji et al. (Ed.), Proceedings of the Second International Research Seminar on Marketing Communication and Consumer Behavior. La Londe Les Maures.

Okonkwo, U. (2007). Luxury Fashion Branding. London: Palgrave Macmillan. https://doi.org/10.1057/9780230590885

Okonkwo, U. (2009). Sustaining the luxury brand on the internet. Journal of Brand Management, (16), 302-310. https://doi.org/10.1057/bm.2009.2

Phau, I. \& Prendergast, G. (2000). Consuming luxury brands: The relevance of the rarity principle. Journal of Brand Management, 8(2), 122-138. https://doi.org/10.1057/palgrave.bm.2540013 